\title{
How was mercury sequestered in an ancient 'greenhouse climate' lake?
}

\author{
AleXANDER ANI ${ }^{1}$, DAVE KEIGHLEY ${ }^{1}$
}

${ }^{1}$ University of New Brunswick, Fredericton, NB, Canada. aani@unb.ca; keig@unb.ca

Toxic metals are a common occurrence in organic-rich rock, and it is widely accepted that biogenic processes played a role in metal enrichment. However, exactly when and what processes effectively sequester toxic metals from surface environments for millions of years, and the composition and distribution of organic/mineral phases hosting the metals, remains uncertain. When better understood, the processes could then be adapted to the present-day clean-up of land and water bodies polluted by industrial activity; the distributions could enable separation of the metals from the oil shale during any future extraction and processing of the petroleum in order to avoid polluting modern environments.

Previous geochemical analyses of Green River Formation (GRF) strata in the Uinta and Piceance Creek basins (Utah and Colorado) have identified high concentrations of toxic heavy metals, including mercury, in beds of oil shale. It is interpreted that these beds originated from the accumulation of organic detritus in sodic-carbonate dominated, low sulfate, high alkalinity "Lake Uinta", during the Early Eocene Climatic Optimum.

An optical petrography, LA-ICP-MS, XRF, and SEMEDS study of a $\sim 4.75 \mathrm{~mm} \times 70 \mu \mathrm{m}$ filamentous structure from a GRF oil shale has identified a complex interweaving of carbonaceous material and diagenetic, blocky carbonate fluorapatite (CFA). The CFA also encloses rhombic crystals of ferroan dolomite and micron to sub-micron scale, electrondense metal sulfides, mostly rhombohedral crystals of $\mathrm{HgS}$ (cinnabar). Larger ferroan dolomite crystals and various metal sulfide particles, including spicular $\mathrm{FeS}_{2}$, are present external of the filament, but $\mathrm{HgS}$ is absent.

Based on additional organic geochemistry, and known morphology and behaviour of modern microbial species, the filament is interpreted as fossilized Beggiatoa. It would have inhabited the soupy shallow substrate beneath the alkaline Lake Uinta during a lake regression. Evaporative pumping promoted dolomite precipitation, and the waters also became more sulfidic, promoting FeS precipitation. In alkaline lake waters, $\mathrm{HgS}$ is soluble, but microbial metal detoxification, by oxidation of alkaline-soluble $\mathrm{Hg}$ and $\mathrm{S}$ complexes, may have caused intra-cellular precipitation of $\mathrm{HgS}$. Death of the microbe would have released polyphosphates resulting in Psaturation and crystallization of CFA (or precursor), trapping the $\mathrm{HgS}$ before it dissolved and re-entered the porewaters. 